\title{
1 Determination of NK cell immunophenotype and cytokine profile in 2 patients with Rocky Mountain spotted fever
}

3 Carolina Maynez-Prieto ${ }^{1-2 \dagger}$, Jaime R. Adame-Gallegos ${ }^{1 \dagger}$, Moisés Ramírez-López ${ }^{3}$, Estefanía

4 Quintana-Mendías ${ }^{2}$, Blanca E. Estrada-Aguirre ${ }^{2}$, Maribel Baquera-Arteaga ${ }^{3}$, Diana

5 Manzanera-Ornelas ${ }^{3}$, Enrique Guevara-Macías ${ }^{3}$, Gerardo P. Espino-Solís ${ }^{2}$ *

$6 \quad{ }^{1}$ Facultad de Ciencias Químicas, Universidad Autónoma de Chihuahua, Chihuahua, México.

$7 \quad{ }^{2}$ Laboratorio Nacional de Citometría de Flujo, Facultad de Medicina. Universidad Autónoma de

8 Chihuahua, Chihuahua, México.

$9 \quad{ }^{3}$ Hospital Infantil de Especialidades de Chihuahua, Chihuahua, México.

$10 \dagger$ These authors contributed equally to the paper.

11 * Correspondence:

12 Gerardo P. Espino-Solís

13 gespinos@uach.mx

14 Keywords: Rickettsiosis; cytokine profiles; Natural killer cells subsets; Rocky Mountain spotted fever; tick-borne diseases; FACS; flow cytometry

\section{Abstract}

The intracellular pathogen Rickettsia rickettsii causes tick-borne spotted fever (also called Rocky Mountain spotted fever (RMSF) and is increasingly recognized as an emerging cause of febrile illness in Mexico. However, little is known about the early immune responses to infection. Four RMSF pediatric patients on acute phase and eight healthy controls from Chihuahua, Mexico were recruited. The natural killer cell (NK) immunophenotype and the cytokine profile in peripheral blood were characterized by flow cytometry. The population of cytotoxic NK cells expressing NKG2D was significantly decreased in patients on 3rd day of hospitalization compared to the first sampling on admission. Interleukins IL-6, IL-8, and IL-10 levels were significantly increased in patients upon admission compared to controls. This study shows that circulating NK cells are numerically decreased, while cytokines induce a pro-inflammatory process in patients. 
It is made available under a CC-BY-NC-ND 4.0 International license .

\section{Introduction}

35

36

37

38

39

40

41

42

43

44

45

46

47

48

49

50

51

52

53

54

55

56

57

58

59

60

61

Rocky Mountain spotted fever (RMSF) is a tick-borne disease caused by Rickettsia rickettsii, an obligate intracellular pathogen that belongs to $\alpha$-protobacteria $(1,2)$. In general, tick-borne diseases have been overlooked as neglected tropical diseases despite their global distribution, although their inclusion in the WHO list has been suggested due to their relevance in Public Health (3). In North America, RMSF is a reemerging infectious disease that primarily affects children living in poverty. In Mexico, in the states of Baja California and Sonora, 2,300 cases and 380 deaths were registered in 2016, and it is estimated that fatality rates are higher in children under 10 years of age (4).

Rickettsia invades endothelial cells promoting their dissemination and causing vasculitis that stimulates cell signaling cascades, which leads to cytokine secretion, initiating infiltration into the vascular cell wall and perivascular space of macrophages, CD8+ T lymphocytes, CD4+ T lymphocytes and NK cells (5). In human in vitro models, endothelial cells increase the expression and secretion of cytokines IL-1 (interleukin-1), IL-6 and TNF $\alpha$ (tumor necrosis factor $\alpha$ ); chemokines such as CXCL8 / IL-8 (interleukin-8), CXCL10 / IP-10 (interferon gamma-induced protein 10), CCL2 / MCP-1 (monocyte chemoattractant protein 1), CXCL9 / MIG (interferon gamma-induced monokine) and CCL5 / RANTES that lead to the activation and recruitment of monocytes, NK cells (natural killers) and $\mathrm{T}$ lymphocytes to the site of infection leading to the potentiation of the inflammatory response and its elimination (6-10). Monocytes, immature macrophages that circulate in the bloodstream, when infected promote the spread of the pathogen in the vascular endothelium, causing an increase in microvascular permeability leading to rickettsial vasculitis (11-13).

While NK cells, the main population of innate lymphocytes that coordinate early responses to bacterial infections, participate on the regulation of the immune response to rickettsia, particularly by preventing early endothelial injury that results in tissue damage $(14,15)$. In murine models, it is well established that NK cells are involved in early innate defense against rickettsial infection $(16,17)$. However, in humans, the host's early immune responses have not been well characterized. In this study, we investigated serum cytokine and chemokine and NK responses in febrile children with acute $R$. rickettsii infection.

\section{$2 \quad$ Materials and methods}

\subsection{Study subjects and inclusion criteria}

The study group included four patients with rickettsiosis ( 2 female and 2 males; mean age $\pm \mathrm{SD}, 5 \pm 5$ years) from Children's Hospital of Specialties of the state of Chihuahua and eight healthy controls matched by age and sex ( 6 female and 6 male; mean age \pm SD, $5 \pm 5$ years). Everyone was punctured in the saphenous vein to obtain blood samples that were collected in EDTA anticoagulant tubes. The diagnoses of the patients required the detection of the gltA gene of Rickettsia spp. by polymerase chain reaction (PCR) using test kits, not having a history of autoimmune, cardiovascular, cerebral and / or osteoarticular disorders; secondary acute infectious processes, and ingestion of medications prior to the first sampling. All healthy controls were recruited from the state of Chihuahua, Mexico, which was the same area where the patients were infected. The controls must not have a history of tick bite prior to sampling; autoimmune, cardiovascular, cerebral and / or osteoarticular disorders; acute infectious processes, and ingestion of drugs prior to sampling. 


\subsection{Statement of ethics}

The study protocol complied with the guidelines established in the Regulations of the General Health Law in matters of health research, the Declaration of Helsinki and the Good Clinical Practices issued by the National Bioethics Commission. It was also approved by the Research Ethics Committee of the Faculty of Medicine and Biomedical Sciences of the Autonomous University of Chihuahua with registration number CI-056-19. All participants or their legal representatives gave their consent to take part in the present study, as well as to have the results of this research work published.

\subsection{Cytokine and Chemokine Profiles}

Cytokine and chemokine levels was evaluated from sera samples obtained from patients with rickettsiosis and control donors. For this, the BD cytometric bead array (CBA) human inflammation kit (Catalog No. 551811), human Th1/Th2/Th17 kit (Catalog No. 560484) and human chemokine kit (Catalog No. 552990) were used following the manufacturer's instructions. Briefly, reaction was made from a Master mix containing $5 \mu \mathrm{L}$ of each antibody for the number of reactions to be done. Diluent solution was added to this mixture so that the volume per reaction was $50 \mu \mathrm{L}$ of the Master mix. To this volume, $50 \mu \mathrm{L}$ of the test sample and $25 \mu \mathrm{L}$ of PE were added. The reaction was incubated for $2 \mathrm{~h}$ in the dark. Subsequently, $1 \mathrm{~mL}$ of wash buffer was added, and it was centrifuged for $5 \mathrm{~min}$ at $200 \times g$. Finally, $350 \mu \mathrm{L}$ of wash buffer was added and it was read on an Attune NxT cytometer in which 10,000 events were recorded at a flow of $100 \mu \mathrm{L} / \mathrm{min}$. Results were analyzed with the FlowJo vX.0.7 program. A graph was generated comparing the size (FWD) with the complexity (SSC) of the spheres. In this way the regions of interest corresponding to the fluorescence of PE bound to the antibody were delimited and the fluorescence intensity corresponding to each cytokine was measured. With these values the concentration of each cytokine was calculated in picograms per milliliter $(\mathrm{pg} / \mathrm{mL})$.

\subsection{NK cells Immunophenotype}

$100 \mu \mathrm{l}$ whole blood were obtained from each sample and stained with the following monoclonal antibodies and reagents: anti-CD3 conjugated with Super Bright 600 (Clone: OKT3, \# 63-0037-42), anti-CD16 conjugated with allophycocyanin-H7 (Clone: 3G8, \# 560195), anti-CD56 conjugated with allophycocyanin (Clone: CMSSB, \# 17-0567-42), anti-CD57 conjugated with Pacific Blue (Clone: TB01 , \# 12-0577-42), anti-NKG2D conjugated with Fluorescein Isothiocyanate (Clone: 1D11, \# 115878-42), and anti-NKG2A conjugated with Brilliant TM Blue 700 (Clone: 131411, No. 747926) (all from Thermo Fisher, Waltham, MA). The samples were incubated in the dark for $15 \mathrm{~min}$, then $2 \mathrm{ml}$ of lysis buffer (BD Solution BD FACS TM 10X concentrated lysate, San Diego, CA) were added and incubated in the dark for $10 \mathrm{~min}$. Subsequently, $2 \mathrm{ml}$ of phosphate-buffered saline (PBS) were added and centrifuged at $1.800 \mathrm{rpm}$ for $5 \mathrm{~min}$ to remove supernatant, $2 \mathrm{ml}$ of PBS were added again, and they were centrifuged at 1,800 rpm for $5 \mathrm{~min}$. After removing the supernatant, they were resuspended in $500 \mu 1$ of PBS. Finally, the resuspended samples were acquired in the Attune NxT cytometer and analyzed in Flow Jo software where the gates strategy to identify the populations was determined (Supplementary Figure 1) (version 10; BD science, San Diego, CA).

\section{Results}

Levels of pro-inflammatory cytokines were evaluated (IL-1 $\beta$, IL-6, IL-8, IL-10, IL-12p70 and TNF $\alpha$ ) in sera from children with rickettsiosis in the acute phase of the disease. It was found a significant increase of IL-6, IL-8 and IL-10 in patients upon admission to hospital compared to controls. No variations were found in the concentrations of IL-1 $\beta$, IL-12p70 and TNF $\alpha$ between patients and controls (Figure 1). When determining serum chemokine levels (IP-10, MCP-1, MIG, RANTES and 
119 IL-8), significant increase in IP-10, MCP-1, MIG and IL-8 was found in patients upon admission to

120 hospital compared to controls. Whereas no variation was found in RANTES concentration between 121 patients and controls (Figure 2).

122 Related to cytokines secreted during Th1 / Th2 / Th17 responses (IL-2, IL-4, IL-6, IL-10, IL-17A, IFN$123 \gamma$ and TNF- $\alpha$ ), within the Th1 response, a significant increase in IFN- $\gamma$ was found in patients upon 124 admission to hospital compared to controls. No variation was found for TNF $\alpha$ and IL-2. In the Th2 125 response, a significant increase in IL-6 and IL-10 was found in patients upon admission to the hospital 126 compared to controls, but not with IL-4, where there was no significant variation. In the Th17 response, 127 there was no significant variation of IL-17A between patients and controls (Figure 3).

128 When evaluating the levels of total NK, cytotoxic NK, effector NK, and NK with expression from 129 CD57 NKG2D, NKG2A, a significant decrease in total NK was found and NK with NKG2D 130 expression in patients at admission compared to controls. Likewise, there was a significant decrease in 131 effector NK in the patients on admission compared to the 3rd day (Figure 4).

\section{Discussion}

133 In vivo RMSF studies in humans evaluating circulating levels of inflammatory mediators and NK are scarce, probably due to the limited availability of patient samples. In the present pilot study, it was observed that in pediatric patients with RMSF it was characterized by a systemic increase in several pro-inflammatory cytokines such as IL-6 and IL-8. This increase has also been reported in other studies of patients with $\operatorname{RMSF}(8,18,19)$ reflecting the activation of monocytes / macrophages and endothelial cells infected by rickettsia, and attraction of T and NK lymphocytes $(20,21)$.

Levels of IL-8, IP-10, MCP-1 and MIG showed a significantly high increase in patients upon admission compared to the controls. These chemokine levels are consistent with those reported in pediatric patients infected with $R$. felis during the acute phase, where IL-8, IP-10, and MCP-1 attract immune cells to infection sites and likely reflect initial host responses to $R$. rickettsii (8). Plasma levels of IL10 , a potent inhibitor of TNF $\alpha$ and IL-6, were found to be significantly increased in patients upon admission to hospital. This result is consistent with previous studies in patients with other rickettsiosis ( $R$. africae and $R$. conorii) where a significant increase in IL-10 was observed around day 12 after the onset of symptoms, possibly associated with the prevention of a disproportionate inflammatory response $(18,22)$.

148 There was a decrease observed in circulating NK cells $\left(\mathrm{CD} 3^{-} \mathrm{CD} 56^{+}\right)$in the pediatric patients in this study, that has also been seen in patients with septic shock $(23,24)$, and sepsis due to Gram positive bacteria such as Streptococcus pneumoniae and Staphylococcus aureus, and Gram-negative bacteria of the genus Enterobacteria and Neisseria meningitidis. In these cases, sepsis due to gram-positive bacteria the one that produced a greater decrease in NK cells circulating compared to sepsis due to gram-negative bacteria. This could indicate a persistent activation of NK cells during severe infection by gram-positive bacteria, the elimination of which normally requires highly organized host responses, whereas many gram-negative pathogens, as is the case in this study, could be effectively destroyed by complement and antibodies (25). Furthermore, the observed reduction in the number of NK cells could reflect the activation and displacement of these cells to other tissues (15). Additionally, previous studies in human acute viral infections such as influenza and hepatitis B infection also found a decrease in circulating NK cells, also related to the activation and displacement of these cells to other tissues $(26,27)$. However, other authors have reported an increase in NK cells in severe sepsis due to gramnegative bacteria and acute infection by scrub fever caused by Orienta tsutsugamushi, which could be 
162

163

164

165

166

167

168

169

170

171

172

173

174

175

176

177

178

179

180

181

182

183

184

185

related to increased hematopoiesis, recruitment and auto-proliferation of NK cells in response to cytokines and microbial stimulation $(15,28,29)$. When analyzing the immunophenotype, a decrease in effector NK cells $\left(\mathrm{CD} 56^{\text {bright }} \mathrm{CD} 16^{\mathrm{dim}}\right)$ was observed in the patients on the $3^{\text {rd }}$ day after admission. This was not the case with cytotoxic NK cells (CD56 ${ }^{\text {dim }}$ CD16 ${ }^{\text {bright }}$ ), showing variation between patients and controls. In turn, there was a significant decrease in the expression of NKG2D of the NK cells in the patients upon admission compared to the $3^{\text {rd }}$ day of their hospitalization. This result could be related to the behavior observed during the infection by $O$. tsutsugamushi where, although no significant differences were observed in the proportion of CD56 ${ }^{\text {bright }} /$ CD56 $6^{\text {dim }} \mathrm{NK}$ cell subsets between patients and controls, they exhibited an activated phenotype with higher expression levels of CD69 (29). Based on this information, possibly the patients in this study are also presenting a high level of CD69 expression due to the decrease in the expression of NKG2D, an activating receptor for NK, which participates in the induction of IFN- $\gamma$ secretion and the positive regulation of CD69 (30).

This event in turn could be one of the main causes of the significant increase in IFN- $\gamma$ plasma levels, also described in patients with murine typhus ( $R$. typhi) and in a patient with infection by $R$. slovaca. The early response to IFN- $\gamma$ activates intracellular bactericidal mechanisms to further control the spread of infection $(19,21)$.

In conclusion, the increase in pro-inflammatory cytokines together with the decrease of circulating NKs with NKG2D expression during $R$. rickettsii infection suggest a picture of severe sepsis or septic shock. These data could provide information on the health status of the pediatric patient and given that children represent a particular vulnerable group, it is even more important to be able to make an early diagnosis to treat them properly. However, require additional studies of antibody-dependent cellular cytotoxicity, T and B lymphocytes, to elucidate immune responses during infection by R.rickettsii.

\section{$5 \quad$ Conflict of Interest}

The authors declare no conflicts of interest.

\section{Author Contributions}

GPES: Conceptualization, project administration, supervision, data analysis, review and editing of manuscript. CMP and JRAG: conceptualization, data analysis, original draft, review and editing of manuscript. EQM, BEEA: FACS analysis. MRL, MBA, DMO, EGM: sample collection and patient resources. All authors contributed to this article and approved the submitted version.

\section{$7 \quad$ Funding}

GPES sincerely acknowledges funding from Consejo Nacional de Ciencia y Tecnología (CONACYT), Ciencia Básica Grant No. A1-S-53789. GPES as part of Laboratorio Nacional de Citometría de Flujo appreciates the support from CONACYT- Apoyos para Acciones de Fortalecimiento, Articulación de Infraestructura y Desarrollo de Proyectos Científicos, Tecnológicos y de Innovación en Laboratorios Nacionales Grant No. 315807. CMP and BEEA are supported from CONACYT, Programa de Becas Nacionales from UACH (Scholarship numbers 755772 and 790272, respectively).

\section{Acknowledgments}

Special thanks to Dra. Guadalupe Virginia Nevárez-Moorillón for her critical remarks. Authors also acknowledge, families and staff at Children's Hospital of Specialties of the state of Chihuahua. Dr. 
medRxiv preprint doi: https://doi.org/10.1101/2021.11.21.21266534; this version posted November $24,2021$. The copyright holder for this preprint (which was not certified by peer review) is the author/funder, who has granted medRxiv a license to display the preprint in perpetuity.

It is made available under a CC-BY-NC-ND 4.0 International license .

201 Gumaro Barrios Gallegos, M.C. Gloria Edith Márquez Leos, Dr. Jorge Alain Carmona Sawatsky, and

202 Dra. Leticia Ruiz González from the Health Department of the state of Chihuahua.

\section{References}

204 1. Blanc G, Ngwamidiba M, Ogata H, Fournier PE, Claverie JM, Raoult D. Molecular evolution of Rickettsia surface antigens: Evidence of positive selection. Mol Biol Evol. 2005;22(10):2073-83.

2. Dantas Torres F. Rocky Mountain spotted fever. Vol. 7, Lancet Infectious Diseases. 2007. p.

208

3. Salje J, Weitzel T, Newton PN, Varghese GM, Day N. Rickettsial infections: A blind spot in our view of neglected tropical diseases. PLoS Negl Trop Dis [Internet]. 2021 May 1 [cited 2021 Nov 17];15(5):e0009353. Available from: https://journals.plos.org/plosntds/article?id=10.1371/journal.pntd.0009353

5. Sahni A, Fang R, Sahni SK, Walker DH. Pathogenesis of Rickettsial Diseases: Pathogenic and

4. Álvarez-Hernández G, Roldán JFG, Milan NSH, Lash RR, Behravesh CB, Paddock CD. Rocky Mountain spotted fever in Mexico: past, present, and future. Lancet Infect Dis [Internet]. 2017 Jun 1 [cited 2018 Apr 3];17(6):e189-96. Available from: http://www.ncbi.nlm.nih.gov/pubmed/28365226

6. Groom JR, Luster AD. CXCR3 ligands: redundant, collaborative and antagonistic functions. Jan;14(1):127-52.

7. Osterloh A. Immune response against rickettsiae: lessons from murine infection models. Vol. Inmunol Cell Biol. 2011;89(2). responses in Rickettsia felis infected febrile children, Ghana. Med Microbiol Immunol. 2018;207(3-4):243-8.

9. Rydkina E, Turpin LC, Sahni SK. Rickettsia rickettsii infection of human macrovascular and microvascular endothelial cells reveals activation of both common and cell type-specific host response mechanisms. Infect Immun. 2010;78(6):2599-606.

10. Sahni SK, Rydkina E. Host-cell interactions with pathogenic Rickettsia species. Future Microbiol. 2009;4(3):323-39.

236 13. Tizard I. Veterinary inmunology. Veterinary Inmunology. 2013. 519-521 p. 
medRxiv preprint doi: https://doi.org/10.1101/2021.11.21.21266534; this version posted November $24,2021$. The copyright holder for this preprint (which was not certified by peer review) is the author/funder, who has granted medRxiv a license to display the preprint in perpetuity.

It is made available under a CC-BY-NC-ND 4.0 International license .

237

238

239

240

241

242

243

244

245

246

247

248

249

250

251

252

253

254

255

256

257

258

259

260

261

262

263

264

265

266

267

268

269

270

271

272

273

274

14. Fang R, Ismail N, Walker DH. Contribution of NK cells to the innate phase of host protection against an intracellular bacterium targeting systemic endothelium. Am J Pathol. 2012;181(1):185-95.

15. Guo Y, Patil NK, Luan L, Bohannon JK, Sherwood ER. The biology of natural killer cells during sepsis. Immunology. 2017;153(2):190-202.

16. Billings AN, Feng HM, Olano JP, Walker DH. Rickettsial infection in murine models activates an early anti-rickettsial effect mediated by NK cells and associated with production of gamma interferon. Am J Trop Med Hyg. 2001;65(1):52-6.

17. La Manna MP, Torina A, Agnone A, Blanda V, Caracappa S, Alongi A, et al. Detection of Natural Killer T Cells in Mice Infected with Rickettsia conorii. Transbound Emerg Dis. 2013;60(SUPPL.2):80-5.

18. Jensenius M, Ueland T, Fournier PE, Brosstad F, Stylianou E, Vene S, et al. Systemic inflammatory responses in African tick-bite fever. J Infect Dis [Internet]. 2003 Apr 15 [cited 2021 Oct 9];187(8):1332-6. Available from: https://pubmed.ncbi.nlm.nih.gov/12696016/

19. Rauch J, Eisermann P, Noack B, Mehlhoop U, Muntau B, Schäfer J, et al. Typhus Group Rickettsiosis, Germany, 2010-2017. Emerg Infect Dis [Internet]. 2018 Jul 1 [cited 2021 Oct 9];24(7):1213. Available from: /pmc/articles/PMC6038764/

20. Sahni SK, Rydkina E. Host-cell interactions with pathogenic Rickettsia species. Future Microbiol. 2009;4(3):323-39.

21. Tappe D, Booken N, Boer-Auer A, Rauch J, Schmiedel S, Reich K. Histology and serum cytokine responses in an imported rickettsia slovaca Infection, Germany. Am J Trop Med Hyg [Internet]. 2018 [cited 2021 Oct 9];98(1):248-51. Available from: https://pubmed.ncbi.nlm.nih.gov/29141745/

22. Vitale G, Mansueto S, Gambino G, Mocciaro C, Spinelli A, Rini GB, et al. The acute phase response in Sicilian patients with boutonneuse fever admitted to hospitals in Palermo, 19921997. J Infect [Internet]. 2001 [cited 2021 Oct 9];42(1):33-9. Available from: https://pubmed.ncbi.nlm.nih.gov/11243751/

23. de Pablo R, Monserrat J, Torrijos C, Martín M, Prieto A, Alvarez-Mon M. The predictive role of early activation of natural killer cells in septic shock [Internet]. Vol. 16, Critical Care. Crit Care; 2012 [cited 2021 Oct 9]. Available from: https://pubmed.ncbi.nlm.nih.gov/22405329/

24. Venet F, Davin F, Guignant C, Larue A, Cazalis MA, Darbon R, et al. Early assessment of leukocyte alterations at diagnosis of septic shock. Shock [Internet]. 2010 Oct [cited 2021 Oct 9];34(4):358-63. Available from: https://pubmed.ncbi.nlm.nih.gov/20220566/

25. Holub M, Klučková Z, Helcl M, Přihodov J, Rokyta R, Beran O. Lymphocyte subset numbers depend on the bacterial origin of sepsis. Clin Microbiol Infect [Internet]. 2003 Mar 1 [cited 2021 Oct 9];9(3):202-11. Available from: https://pubmed.ncbi.nlm.nih.gov/12667252/

26. Jost S, Quillay H, Reardon J, Peterson E, Simmons RP, Parry BA, et al. Changes in cytokine levels and NK cell activation associated with influenza. PLoS One [Internet]. 2011 Sep 23 
medRxiv preprint doi: https://doi.org/10.1101/2021.11.21.21266534; this version posted November $24,2021$. The copyright holder for this preprint (which was not certified by peer review) is the author/funder, who has granted medRxiv a license to display the preprint in perpetuity.

It is made available under a CC-BY-NC-ND 4.0 International license .

[cited 2021 Oct 9];6(9). Available from: https://pubmed.ncbi.nlm.nih.gov/21966414/

27. Zheng Q, Zhu YY, Chen J, Ye YB, Li JY, Liu YR, et al. Activated natural killer cells accelerate liver damage in patients with chronic hepatitis B virus infection. Clin Exp Immunol [Internet]. 2015 Jun 1 [cited 2021 Oct 9];180(3):499-508. Available from: https://pubmed.ncbi.nlm.nih.gov/25639451/

28. Giamarellos-Bourboulis EJ, Tsaganos T, Spyridaki E, Mouktaroudi M, Plachouras D, Vaki I, et al. Early changes of CD4-positive lymphocytes and NK cells in patients with severe Gramnegative sepsis. Crit Care [Internet]. 2006 Nov 27 [cited 2021 Oct 9];10(6). Available from: https://pubmed.ncbi.nlm.nih.gov/17129388/

29. Kang SJ, Jin HM, Cho YN, Kim SE, Kim UJ, Park KH, et al. Increased level and interferon- $\gamma$ production of circulating natural killer cells in patients with scrub typhus. PLoS Negl Trop Dis [Internet]. 2017 Jul 27 [cited 2021 Oct 9];11(7). Available from: https://pubmed.ncbi.nlm.nih.gov/28750012/

30. Stojanovic A, Correia MP, Cerwenka A. The NKG2D/NKG2DL axis in the crosstalk between lymphoid and myeloid cells in health and disease [Internet]. Vol. 9, Frontiers in Immunology. Front Immunol; 2018 [cited 2021 Oct 9]. Available from: https://pubmed.ncbi.nlm.nih.gov/29740438/

\section{Supplementary Material}

Supplementary Figure 1. Gating strategy and identification of human NK cells. Whole blood was incubated with target cells for 15 minutes at $4^{\circ} \mathrm{C}$, surface stained with fluorochrome-conjugated antiCD3, anti-CD16, anti-CD56, anti-CD57, anti-NKG2Aand anti-NKG2D mAbs. Profiles demonstrate the gating strategy [side scatter (SSC) vs. forward scatter (FCS) and CD56 vs. CD3] for identification of NK cells $\left(\mathrm{CD}^{-\mathrm{CD} 56^{+}}{ }^{+}\right.$), effector $\mathrm{NK}$ cells (CD16 $\left.{ }^{\text {dim }} \mathrm{CD} 56^{\text {bright }}\right)$, cells Cytotoxic NKs $\left(\mathrm{CD} 16^{\text {bright }} \mathrm{CD} 56^{\mathrm{dim}}\right)$, CD57-expressing $\mathrm{NK}$ cells $\left(\mathrm{CD} 56^{+} \mathrm{CD} 57^{+}\right)$, NK cells expressing NKG2D $\left(\mathrm{CD} 56^{+} \mathrm{NKG}^{+} \mathrm{D}^{+}\right)$and $\mathrm{NK}$ cells expressing $\mathrm{NKG} 2 \mathrm{~A}\left(\mathrm{CD} 56^{+} \mathrm{NKG}^{2} \mathrm{~A}^{+}\right)$cell populations. Profiles also show CD56 versus CD57, NKG2A and NKG2D staining on CD3 ${ }^{-}$CD56 $6^{+} \mathrm{NK}$ cells for one representative donor after incubation of whole blood sample with indicated target cells, analysis was carried out with FlowJo software.

\section{Figure legends}

Figure 1. Proinflammatory cytokine levels in sera from children with rickettsiosis during the acute phase. Four sera from children infected with Rickettsia rickettsii and eight sera from healthy children were analyzed in parallel by the bead-based human inflammatory cytokine kit assay. Data are expressed as mean \pm SD. Statistical analyzes were performed with the test of Kruskal-Wallis and Dunn's subsequent multiple comparison test. Asterisks indicate differences statistically significant (* $\mathrm{p}<0.05, * * \mathrm{p}<0.01)$.

Figure 2. Chemokine levels in sera from patients with acute rickettsiosis. Sera obtained from children infected with Rickettsia rickettsii and eight sera from healthy children were analyzed in parallel by the bead-based human chemokine kit assay. Data are expressed as mean \pm SD. Statistical analyzes were performed with the test of Kruskal-Wallis and Dunn's subsequent multiple comparison test. Asterisks indicate differences statistically significant $(* \mathrm{p}<0.05, * * \mathrm{p}<0.01)$. 
medRxiv preprint doi: https://doi.org/10.1101/2021.11.21.21266534; this version posted November 24, 2021. The copyright holder for this preprint (which was not certified by peer review) is the author/funder, who has granted medRxiv a license to display the preprint in perpetuity.

It is made available under a CC-BY-NC-ND 4.0 International license .

315 Figure 3. Levels of cytokines involved in Th1 / Th2 / Th17 responses in sera from children with

316 rickettsiosis during the acute phase. Sera obtained from children infected with Rickettsia rickettsii

317 and eight sera from healthy children were analyzed in parallel by the bead-based human Th1 / Th2 /

318 Th17 cytokine kit assay. Data are expressed as mean \pm SD. Statistical analyzes were performed with

319 the test of Kruskal-Wallis and Dunn's subsequent multiple comparison test. Asterisks indicate

320 differences statistically significant $(* \mathrm{p}<0.05$, ** $\mathrm{p}<0.01)$.

321 Figure 4. Percentage of NK cells $\left(\mathrm{CD3}^{-} \mathrm{CD56}^{+}\right)$, effector NK cells $\left(\mathrm{CD}^{\mathrm{dim}} \mathrm{CD56}^{\mathrm{bright}}\right)$, cells 322 Cytotoxic NKs $\left(\mathrm{CD}_{16}{ }^{\text {bright }} \mathrm{CD56}^{\mathrm{dim}}\right)$, CD57-expressing NK cells $\left(\mathrm{CD56}^{+} \mathrm{CD57}^{+}\right)$, NK cells 323 expressing NKG2D $\left(\mathrm{CD56}^{+} \mathrm{NKG}^{+} \mathrm{D}^{+}\right)$and $\mathrm{NK}$ cells expressing $\mathrm{NKG}^{\mathrm{A}}\left(\mathrm{CD56}^{+} \mathrm{NKG2A}^{+}\right)$in 324 blood obtained from children with rickettsiosis during the acute phase and healthy controls. Two 325 analyzes were performed on parallel in four sera from children with rickettsiosis. The first analysis 326 upon admission to the hospital and a second analysis 3 days after treatment, and the second serum from 327 healthy blood donor children. The data are expressed as mean \pm SD. Statistical analyzes were 328 performed with the Kruskal-Wallis test and the subsequent Dunn multiple comparison test. Asterisks 329 indicate differences statistically significant $(\mathrm{p}<0.01)$. 
medRxiv preprint doi: https://doi.org/10.1101/2021.11.21.21266534; this version posted November 24, 2021. The copyright holder for this preprint (which was not certified by peer review) is the author/funder, who has granted medRxiv a license to display the preprint in perpetuity.
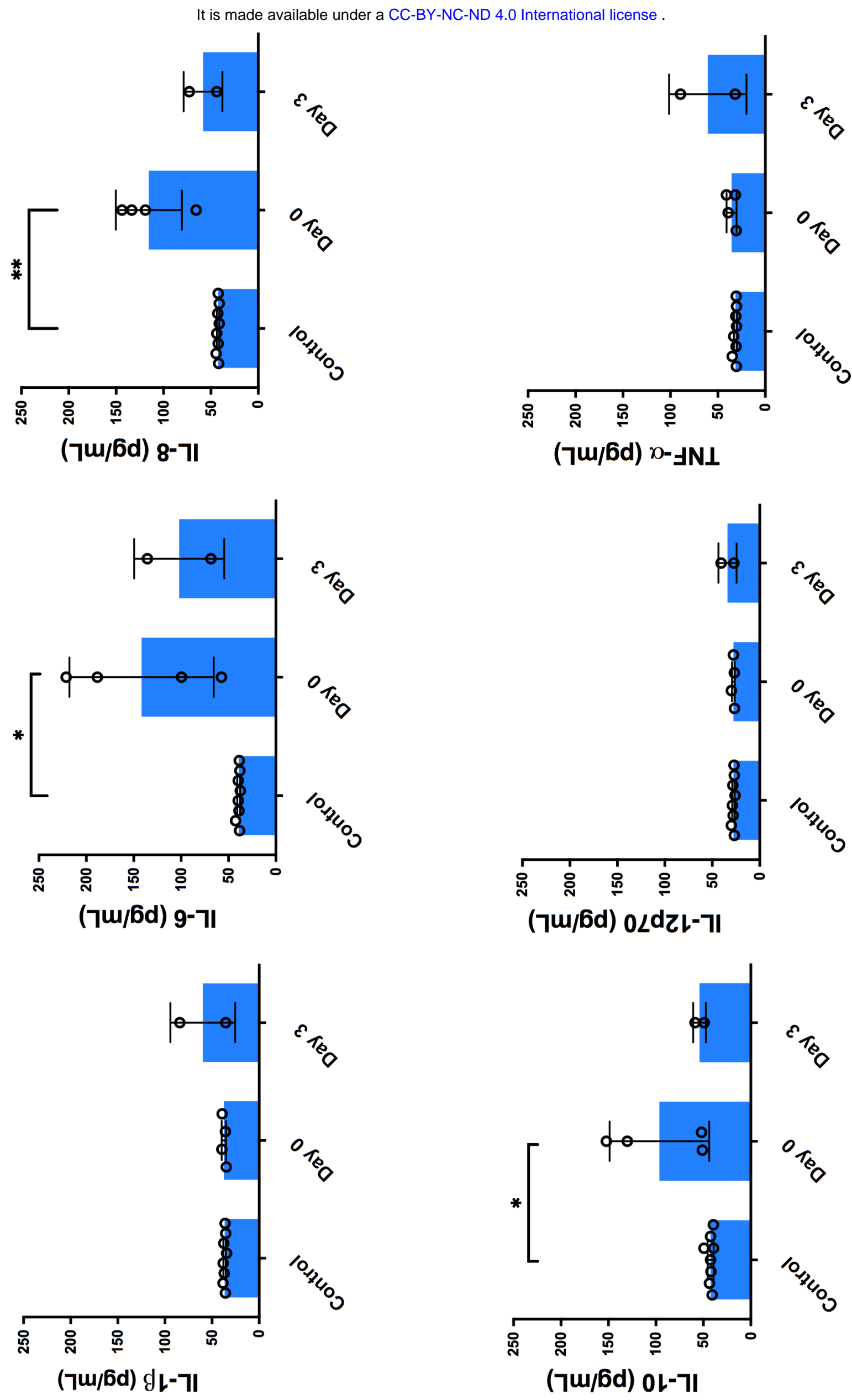
medRxiv preprint doi: https://doi.org/10.1101/2021.11.21.21266534; this version posted November 24, 2021. The copyright holder for this preprint (which was not certified by peer review) is the author/funder, who has granted medRxiv a license to display the preprint in perpetuity.

It is made available under a CC-BY-NC-ND 4.0 International license .

Figure 2
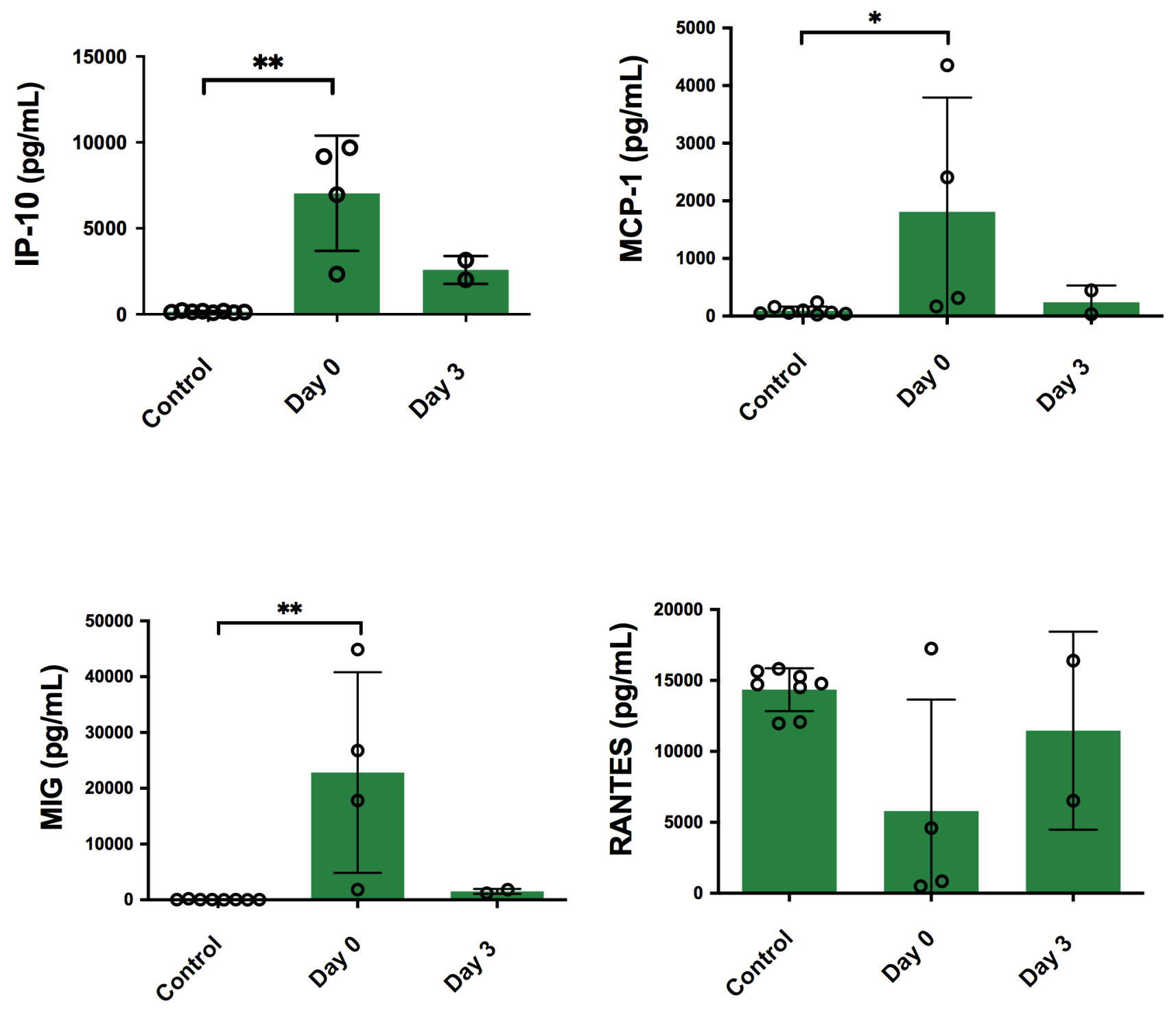
medRxiv preprint doi: https://doi.org/10.1101/2021.11.21.21266534; this version posted November 24, 2021. The copyright holder for this preprint (which was not certified by peer review) is the author/funder, who has granted medRxiv a license to display the preprint in perpetuity.

It is made available under a CC-BY-NC-ND 4.0 International license .
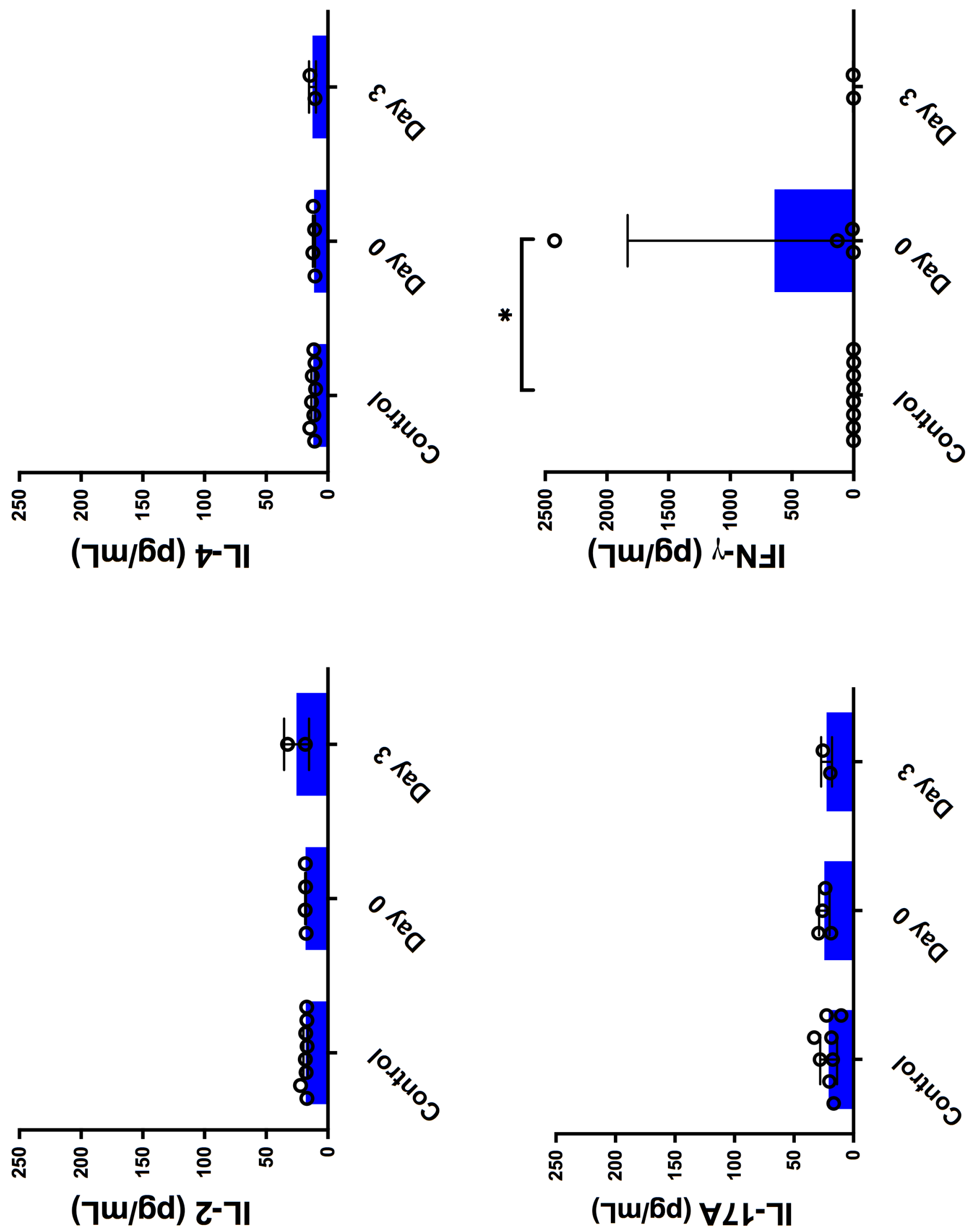
medRxiv preprint doi: https://doi.org/10.1101/2021.11.21.21266534; this version posted November 24, 2021. The copyright holder for this preprint (which was not certified by peer review) is the author/funder, who has granted medRxiv a license to display the preprint in perpetuity.

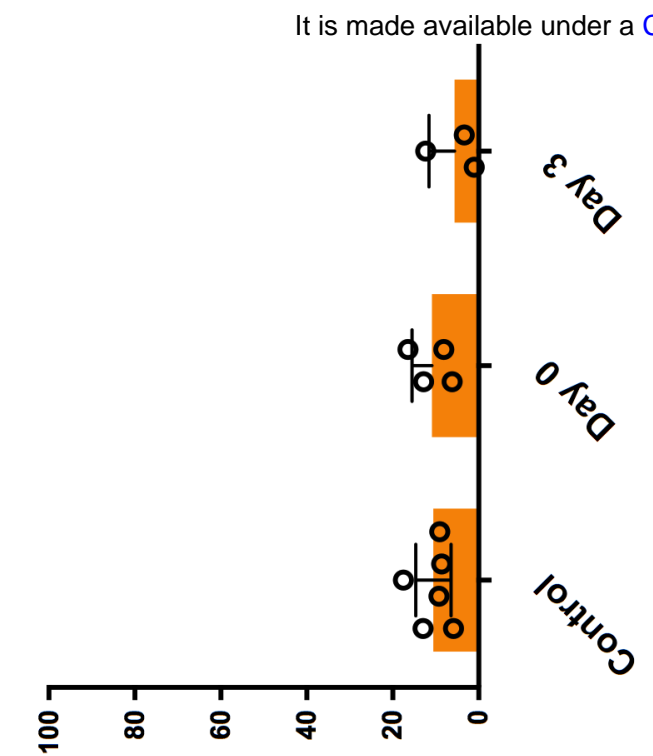

(\%) ұ46!ıq990ว щ!p9Lवว

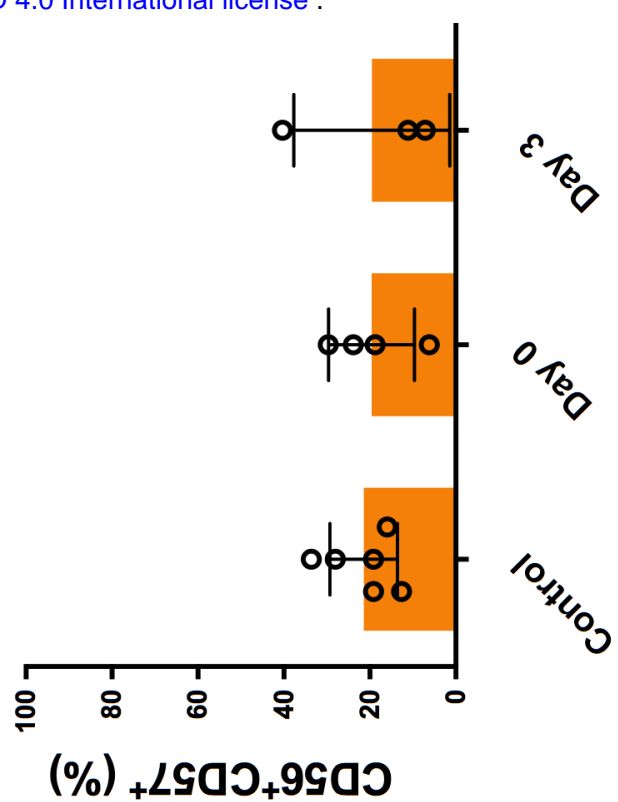

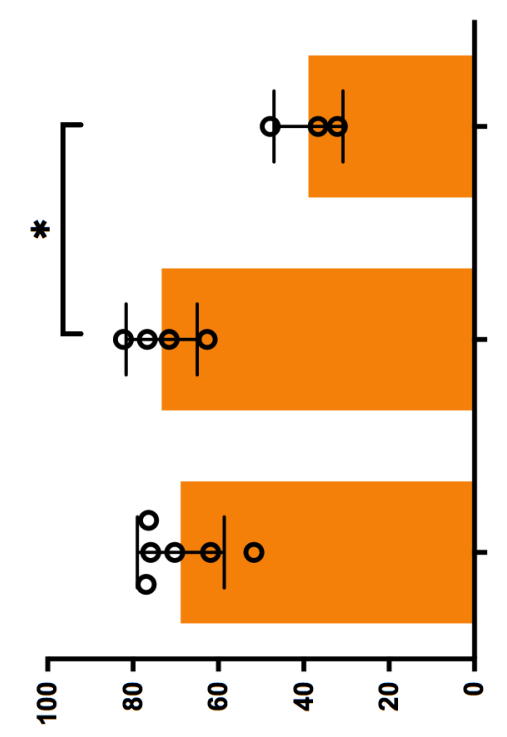

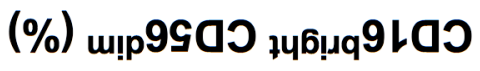

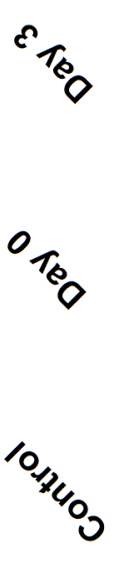

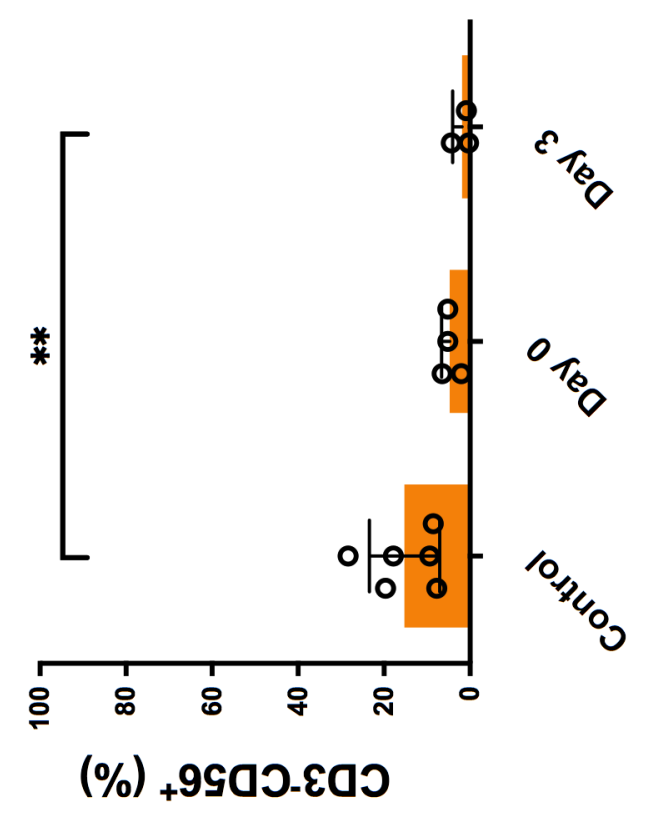

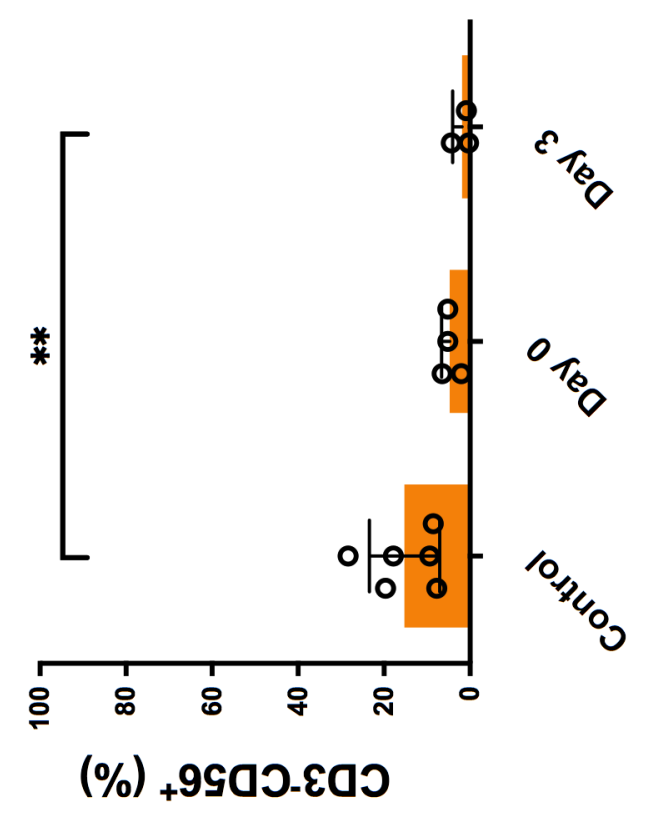

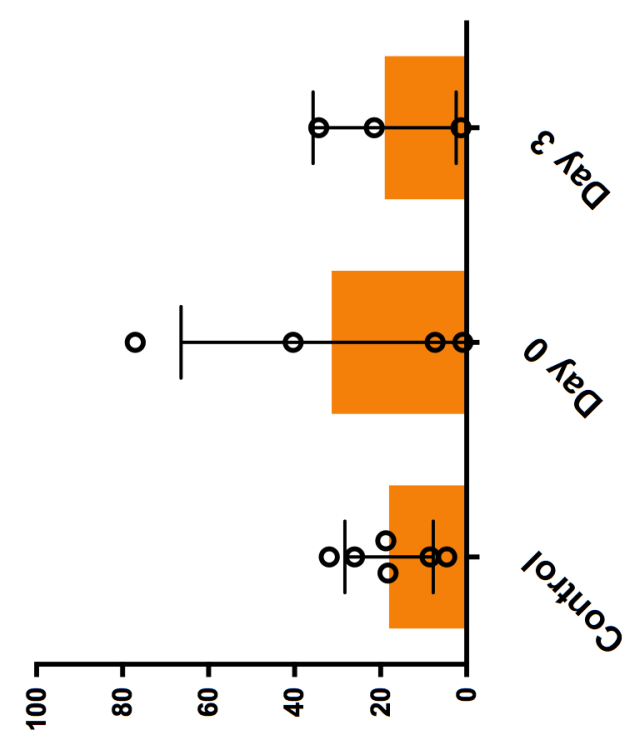

(\%) + $\forall Z$ ZYN+9S0J

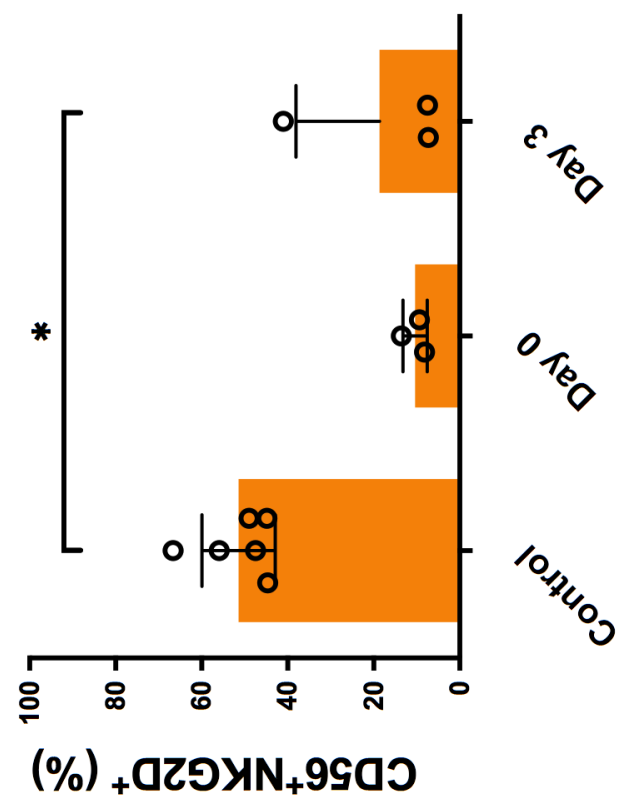


medRxiv preprint doi: https://doi.org/10.1101/2021.11.21.21266534; this version posted November 24, 2021. The copyright holder for this preprint (which was not certified by peer review) is the author/funder, who has granted medRxiv a license to display the preprint in perpetuity.

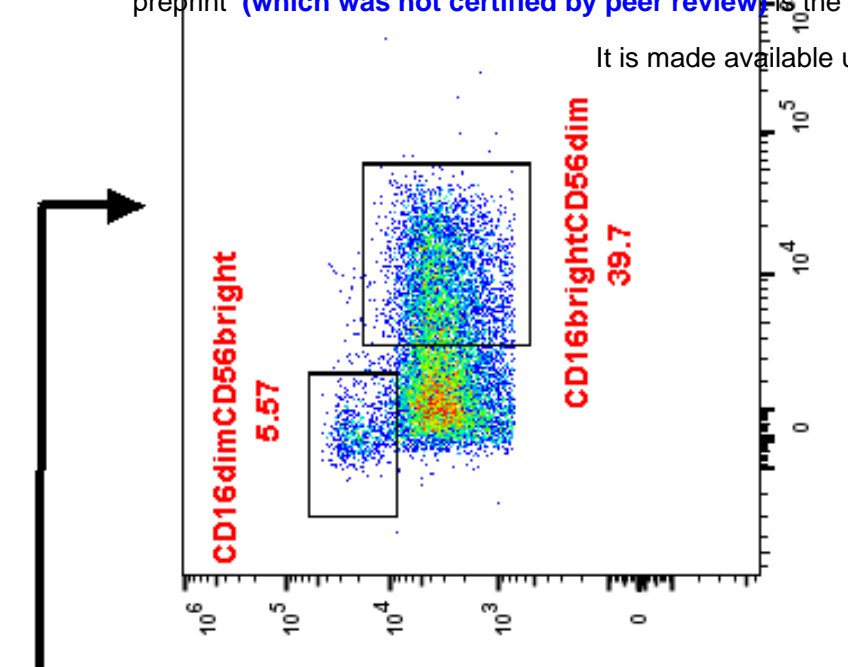

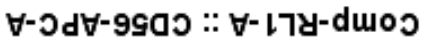

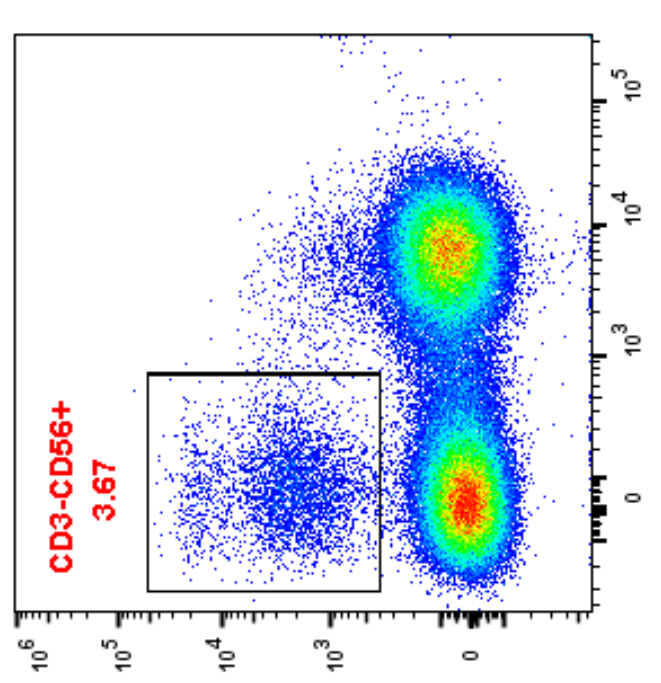

든
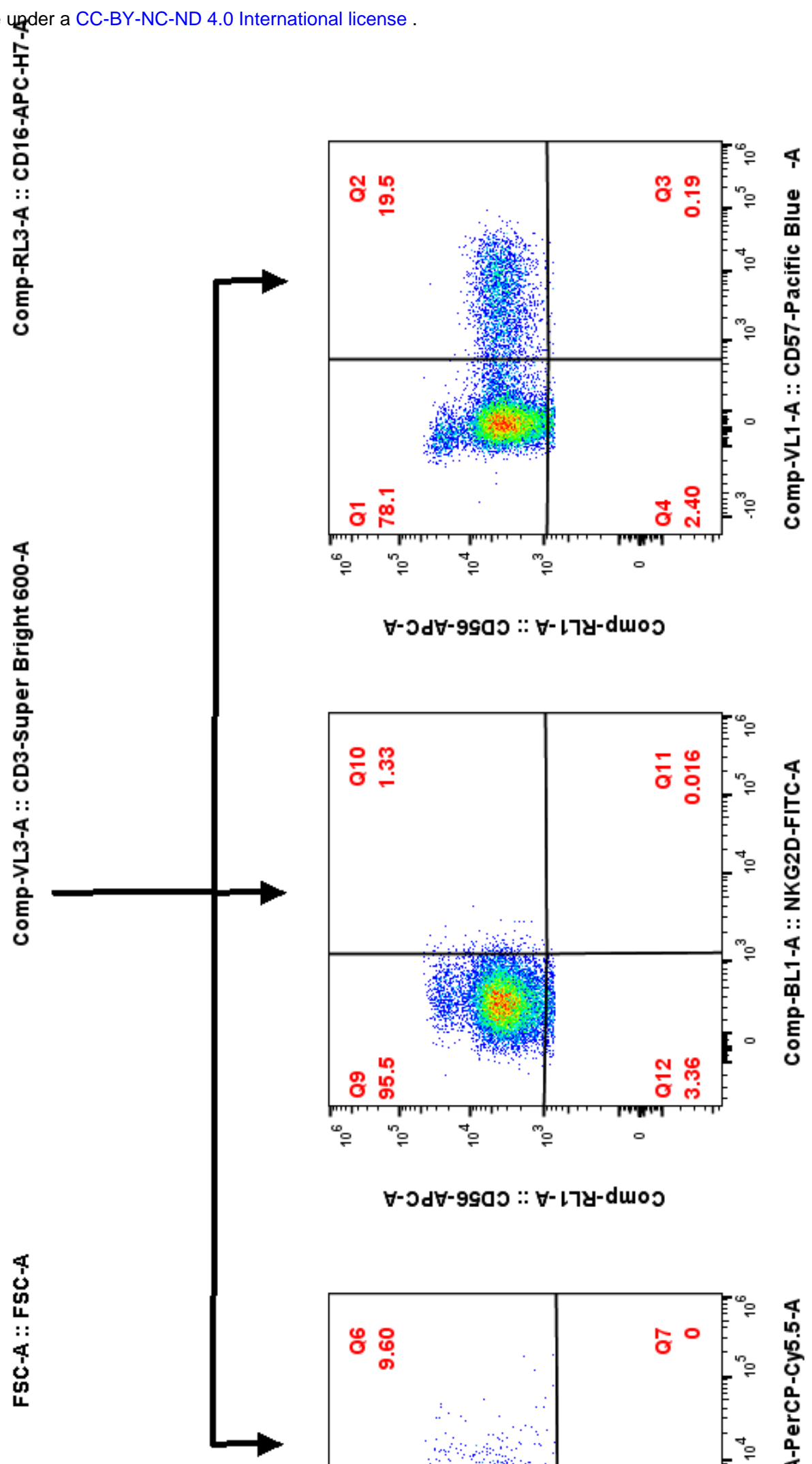

$\forall-0 d \forall-9 g a 0:: \forall-17$ -

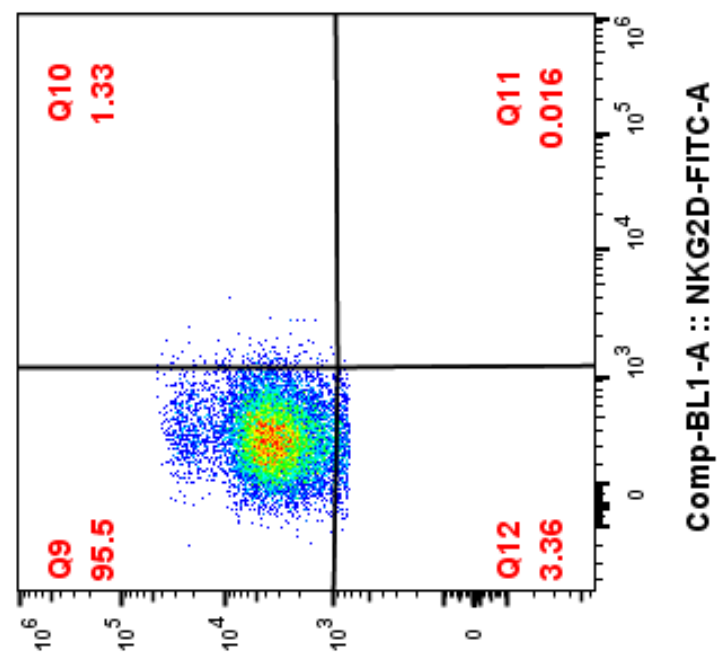

$\forall-0 d \forall-9 s 00:: \forall-l 7 y-d m o 0$

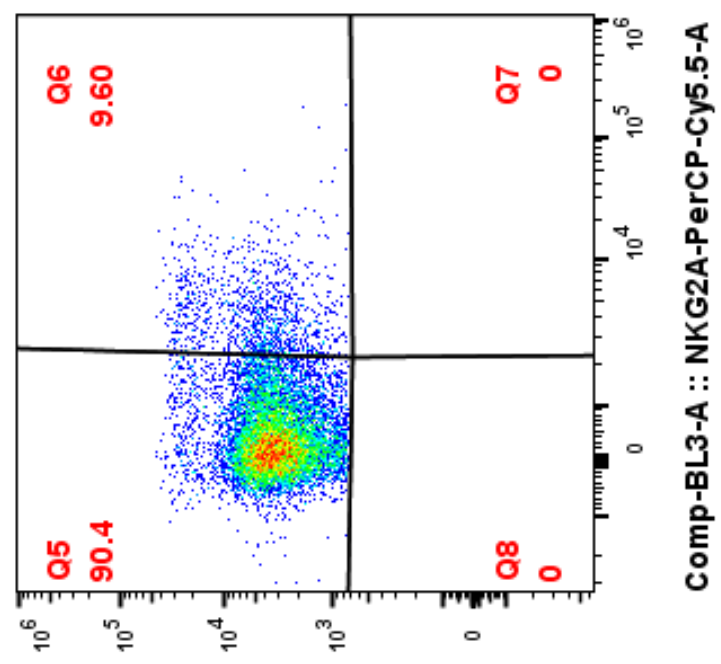

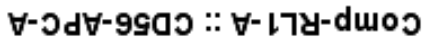

